\title{
Phytol and Peroxisome Proliferation
}

\author{
CHRISTIANE VAN DEN BRANDEN, JOSEPH VAMECQ, INGRID WYBO, AND FRANK ROELS \\ Laboratorium voor Menselijke Anatomie, Vrije Universiteit Brussel [C.V.d.B., I.W., F.R.] and Laboratoire de \\ Chimie Physiologique, Université Catholique de Louvain and International Institute of Cellular and Molecular \\ Pathologie, [J.V.], Brussels, Belgium
}

\begin{abstract}
Infantile Refsum's disease is characterized by high levels of phytanic acid and the absence of normal hepatic peroxisomes. We investigated the in vivo influence of phytol, a precursor of phytanic acid, on peroxisomes by both biochemical and morphological methods. Enhanced supply of phytol in the diet of adult mice causes proliferation of hepatic peroxisomes. The peroxisomal $\beta$-oxidizing capacity as well as exchanges of acyl moieties between peroxisomes and mitochondria are raised around 5- and 2fold, respectively. In parallel a 1.5-fold increase of total catalase and mitochondrial butyryl-CoA dehydrogenase activities occurs, whereas peroxisomal urate oxidase and glycolate oxidase remain normally active. Serum triglyceride levels are decreased after 3 wk of phytol feeding; serum cholesterol levels remain unaffected. Phytol feeding also induces peroxisome proliferation in duodenal epithelium, in myocardium and in skin sebaceous glands, but not in kidney. (Pediatr Res 20: 411-415, 1986)
\end{abstract}

Phytanic acid is a minor lipid component of normal human serum. In patients with adult-onset Refsum's disease this fatty acid accumulates in the lipids of several tissues $(1,2)$. The metabolic defect resulting from an impairment of the $\alpha$-oxidation system is clinically revealed by crisis occuring in the course of nutritional overload by phytanic acid (2-4). Phytanic acid and its precursor phytol are present in most diets (5). In humans and other mammalian species, phytol is easily converted to phytanic acid, which is otherwise not synthesized in the body (6-9). Attempts to induce symptoms analogous to those of adult-onset Refsum's disease by feeding animals phytol or phytanic acid were unsuccessful $(10,11)$. However, it was possible to increase the phytanic acid levels in serum and in most tissues to values found in the adult Refsum patients (2). After only 2 days of a $2 \%$ phytol diet mouse liver contains significant amounts of phytanic acid and its metabolites, whereas in control livers these acids were not detectable (12)

Besides the classical adult-onset Refsum's disease, another disorder has recently been described, mainly affecting young children, the infantile Refsum's disease $(13,14)$. Cytochemistry and electron microscopy demonstrate the absence of normal peroxisomes in liver biopsies from these children $(15,16)$. This finding and the presence of high levels of very long chain fatty acids and abnormal bile acid intermediates in infantile Refsum patients $(17,18)$ indicate a link with two other neonatal "per-

Received July 31, 1985; accepted December 30, 1985

C. Van den Branden, Menselijke Anatomie, VUB, 103 Laarbeeklaan, B-1090 Brussels, Belgium.

This work was supported by the Belgian F.G.W.O., Grant 3.0071.83. J.V. is Aspirant of the Belgian Fonds Nationaal de la Recherche Scientifique. C.V.d.B. is indebted to the Belgian Nationaal Fonds voor Wetenschappelijk Onderzoek for financial support. oxisomal diseases," Zellweger's cerebrohepatorenal syndrome and adrenoleukodystrophy (autosomic recessive), in which peroxisomes are either absent or lacking several functions (19-24). The ultrastructural and biological findings reported in infantile Refsum's disease have not yet been examined in adult-onset Refsum's disease; peroxisomes were studied in cultured fibroblasts from adult-onset Refsum patients, but not in other cell types (24). It was recently demonstrated that certain metabolites (hypoglycin) can have a destructive effect on rat liver peroxisomes (25). We now investigate the effect of phytanic acid accumulation following enhanced dietary supply of phytol on peroxisomal abundance and enzymology in several organs from mice. We also discuss the possible role of peroxisomes in the catabolism of phytanic acid.

\section{MATERIALS AND METHODS}

Adult Swiss mice (40-45 g) were used. Phytol-fed mice received a diet containing meal (A04-UAR, Epinay, France) and phytol, diluted with soya oil to facilitate resorption (6). Phytol concentration in the diet ranged from 0.05 to $5 \%(\mathrm{w} / \mathrm{w})$; soya oil was added to a final concentration of $10 \%(\mathrm{w} / \mathrm{w})$. Matched control mice received meal $+10 \%$ soya oil $(w / w)$. Phytol $(95 \%)$ was obtained from Serva Feinbiochemica, Heidelberg, Germany). Diets were given during 3 to 21 days. Before sacrifice animals were starved overnight.

Catalase (EC 1.11.1.6) activity was assayed in total liver homogenate as described earlier (26). Palmitoyl-CoA oxidase (EC 1.1.3.-), L- $\alpha$-hydroxyacid oxidase (EC 1.1.3.1) and urate oxidase (EC 1.7.3.3) activities were measured according to Vamecq and Van Hoof (27). Carnitine acetyltransferase (EC 2.3.1.7), carnitine octanoyltransferase (EC 2.3.1.-), and carnitine palmitoyltransferase (EC 2.3.1.23) were assayed, respectively, on $0.1 \mathrm{mM}$ acetyl$\mathrm{CoA}, 0.1 \mathrm{mM}$ hexanoyl-CoA, and $0.1 \mathrm{mM}$ palmitoyl-CoA as substrates by the method B (28). Butyryl-CoA dehydrogenase assay was performed as described previously (29).

Serum cholesterol was determined by an enzymatic colorimetric method (30). Serum triglycerides were determined by a fully enzymatic UV procedure (31).

Each experimental group consisted of at least four animals. All results are presented as the mean \pm SEM. For statistical analysis the Mann-Whitney test was used (32).

Tissue slices of $0.5-\mathrm{mm}$ thickness (liver, kidney, adrenal gland, myocardium, duodenum, and skin) were fixed at room temperature in $4 \%$ formol-calcium buffered with cacodylate for $24 \mathrm{~h}$. Chopper sections $(50 \mu \mathrm{m})$ and cryostat sections $(20$ and $5 \mu \mathrm{m})$ were stained for catalase (33). The specificity of the diaminobenzidine reaction was discussed previously (34). Chopper sections were postosmicated and embedded in Epon. Cryostat sections were mounted in a water soluble medium after postosmication or stained with toluidine blue and mounted through xylene. For electron microscopy $600 \AA$ sections were poststained with lead only. 


\section{RESULTS}

After 3 days of phytol diet the catalase activity of the liver has significantly increased (Table 1). A phytol dose of $0.05 \%$ is not effective; a large dosis of $5 \%$ is only slightly more effective than a $0.5 \%$ dosis and provokes serious distress in the animals. For the last reason the dosis of $0.5 \%$ phytol was chosen for further experiments. After 11 days of this diet, liver catalase activity is increased; this increase is not more pronounced than after 3 days. The increase of liver catalase activity is present in both male and female animals.

The influence of a $0.5 \%$ phytol diet during 11 days on seven liver enzyme activities is summarized in Table 2 . The peroxisomal $\beta$-oxidation specifically measured by its first step is increased more than 5-fold, while two other peroxisomal enzymes, $L-\alpha-$ hydroxyacid oxidase type A and urate oxidase keep their normal activity. Peroxisomal carnitine octanoyltransierase and total mitochondrial carnitine palmitoyltransferase also display more activity as does total liver carnitine acetyltransferase. Butyryl-CoA dehydrogenase, a marker enzyme of the mitochondrial matrix, was also assayed and its activity was found to be 1.5-fold higher in phytol-treated than in control liver.

Serum cholesterol levels are not decreased after 21 days of a $0.5 \%$ phytol diet; triglyceride levels on the contrary decrease significantly during this period (Table 3 ).

Liver sections of $20 \mu \mathrm{m}$ show a marked increase in catalase staining after 0.5 and $5 \%$ phytol for 3 and 11 days, but not after $0.05 \%$ phytol, when compared to control animals. One- $\mu \mathrm{m}$ Epon sections give evidence that the number of peroxisomes is raised by feeding 0.5 and $5 \%$ phytol (Fig. 1), and not raised by $0.05 \%$. Individual peroxisomes also appear larger and more darkly

Table 1. Influence of phytol on mouse liver catalase activity after 3 and 11 days of phytol diet*

\begin{tabular}{lcc}
\hline \multicolumn{1}{c}{ Conditions } & $\begin{array}{c}\text { Catalase } \\
\left(\mathrm{U}_{\mathrm{B}} / \mathrm{g} \text { of liver }\right)\end{array}$ & Ratio \\
\hline Controls & $90 \pm 1$ & \\
3 days of phytol diet & & \\
$0.05 \%$, male & $98 \pm 4$ & 1.09 \\
$0.5 \%$, male & $163 \pm 3$ & 1.81 \\
$5 \%$, male & $178 \pm 5$ & 1.98 \\
$0.5 \%$, female & $140 \pm 5$ & 1.56 \\
$5 \%$, female & $174 \pm 5$ & 1.93 \\
11 days of phytol diet & & \\
$0.5 \%$, male & $138 \pm 6$ & 1.53 \\
\hline
\end{tabular}

* All phytol influenced catalase values are significantly different from controls $(p<0.01)$ except the $0.05 \%$ value.

Table 2. Influence of 11 days of a $0.5 \%$ phytol diet on liver enzymes in adult male mice*

\begin{tabular}{lccl}
\hline \multicolumn{1}{c}{ Enzymes } & Controls & $\begin{array}{c}0.5 \% \text { Phytol } \\
\text { fed }\end{array}$ & Ratio \\
\hline Palmitoyl-CoA oxidase & $522 \pm 31$ & $2666 \pm 319$ & $5.11 \dagger$ \\
L- $\alpha$-Hydroxyacid oxidase & $278 \pm 31$ & $281 \pm 22$ & 1.01 \\
$\quad$ (type A) & $737 \pm 95$ & $665 \pm 34$ & 0.90 \\
$\begin{array}{l}\text { Urate oxidase } \\
\text { Carnitine palmitoyltrans- } \\
\quad \text { ferase }\end{array}$ & $1231 \pm 66$ & $1856 \pm 159$ & $1.51 \dagger$ \\
$\begin{array}{l}\text { Carnitine octanoyltrans- } \\
\text { ferase }\end{array}$ & $2306 \pm 87$ & $5044 \pm 259$ & $2.19 \dagger$ \\
$\begin{array}{c}\text { Carnitine acetyltransfer- } \\
\text { ase }\end{array}$ & $239 \pm 41$ & $680 \pm 92$ & $2.85 \dagger$ \\
$\begin{array}{c}\text { Butyryl-CoA dehydro- } \\
\text { genase }\end{array}$ & $731 \pm 28$ & $1063 \pm 23$ & $1.45 \dagger$ \\
\hline
\end{tabular}

\footnotetext{
* Enzyme activities are expressed as nmol of substrate consumed or product formed per min and per $\mathrm{g}$ of liver.

$\dagger p<0.01$.
}

Table 3. Influence of phytol diet on adult male mouse serum cholesterol and triglyceride levels

\begin{tabular}{lcc}
\hline \multicolumn{1}{c}{ Conditions } & $\begin{array}{c}\text { Cholesterol } \\
(\mathrm{mg} / \mathrm{dl})\end{array}$ & $\begin{array}{c}\text { Triglycerides } \\
(\mathrm{mg} / \mathrm{dl})\end{array}$ \\
\hline $\begin{array}{l}\text { Controls } \\
3 \text { days of phytol diet }\end{array}$ & $120 \pm 5$ & $115 \pm 10$ \\
$\quad \begin{array}{l}0.05 \% \\
0.5 \%\end{array}$ & $139 \pm 4$ & $108 \pm 14$ \\
$\begin{array}{l}11 \text { days of phytol diet } \\
0.5 \%\end{array}$ & $108 \pm 5$ & $120 \pm 22$ \\
$\begin{array}{l}21 \text { days of phytol diet } \\
0.5 \%\end{array}$ & $106 \pm 10$ & $145 \pm 30$ \\
\hline
\end{tabular}

$* p<0.01$.

stained than in controls. A difference between 0.5 and $5 \%$ is visible. Proliferation and enlargement of peroxisomes is confirmed by electron microscopy (Fig. 2). The subcellular organelles are otherwise normally shaped.

No peroxisomes are visible by light microscopy in 4- $\mu \mathrm{m}$ Epon sections of duodenum in control and $0.5 \%$ phytol-fed mice. Peroxisome proliferation is noticed in the duodenal epithelial cells of mice fed $5 \%$ phytol during 5 days. This proliferation is most pronounced at the base of the villi (Fig. $3 a$ and $b$ ).

In skin sebaceous glands of $5 \%$ phytol-fed mice ( 5 days) peroxisomes are visible in Epon sections (Fig. $3 c$ and $d$ ). This is not the case in the other groups.

In mouse myocardium light microscopy shows no visible peroxisomes in control animals. In 5\% phytol treated mice peroxisomes are present (Fig. $3 e$ and $f$ ).

Peroxisome proliferation in liver, duodenum, skin sebaceous glands, and myocardium is observed in male and female mice.

Cryostat sections of kidneys show no difference between control and phytol-fed animals. In adrenal glands very few and small peroxisomes are seen both in controls and in treated mice.

It seems important to stress the toxicity of phytol to animals $(6,35,36)$. Mice fed with $0.5 \%$ phytol did not show any signs of distress. Mice fed a $5 \%$ phytol diet became ill sometimes after 3 or 4 days; they lose appetite, start shivering, and show the changes in the skin described by Klenk and Kremer (6).

\section{DISCUSSION}

Children with infantile Refsum's disease possess abnormal microbodies without catalase, or no microbodies at all $(15,16)$. Whereas in the adult form of Refsum's disease the localization of the enzyme defect, i.e. phytanic acid oxidase deficiency, is well established, reasons for impaired metabolism of phytanic acid in the infantile form remain to be elucidated. Selective accumulation of one or several intermediates of phytanic acid catabolism in infantile Refsum's disease cannot be definitely ruled out. As in the case of hypoglycin (25), such metabolites might be toxic for peroxisomes. Overload of the entire set of reactions leading to phytanic acid breakdown has been achieved by exogenous administration of high doses of phytol to mice. Our experiments show that enhanced supply of phytol in the diet of mice is not destructive to peroxisomes. Actually, the number and size of peroxisomes is increased in liver and in several other organs, with a cytochemical picture contrasting to the situation observed in liver from infantile Refsum patients $[15,16)$.

We also demonstrate that phytol feeding $(0.5 \%)$ increases the activity of peroxisomal $\beta$-oxidation. It has no effect on other peroxisomal marker enzymes. Carnitine acyltransferases involved in fatty acid metabolism show increased activity but less than the peroxisomal fatty acyl-CoA oxidase. Although both peroxisome proliferators are chemically very different, the parallel which can be drawn between the effects of phytol and clofibrate on the enzymes investigated is striking: stimulation of peroxisomal $\beta$-oxidation and increased capacity to metabolise 


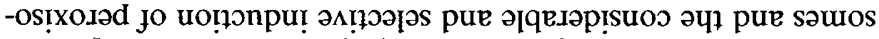

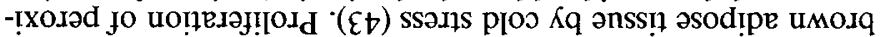

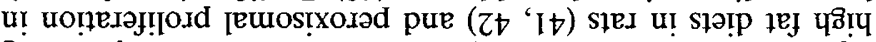

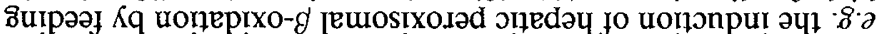

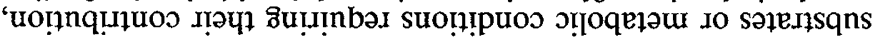

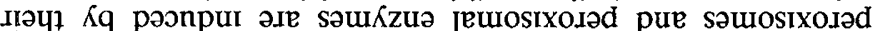

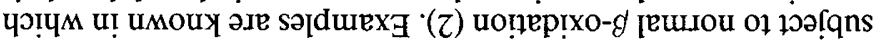

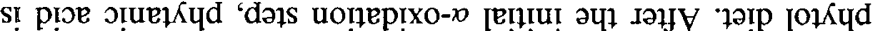

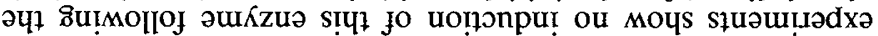

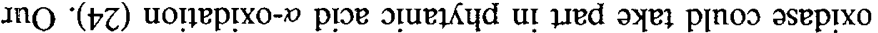
p!วe $\Lambda$ ХO

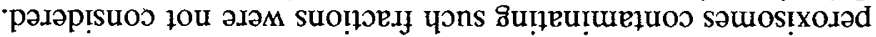

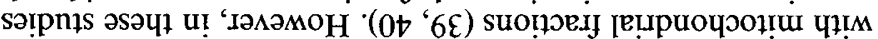

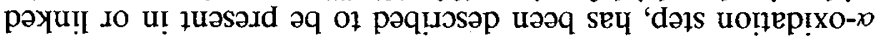

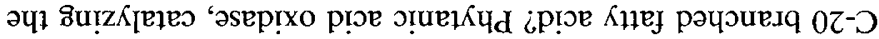

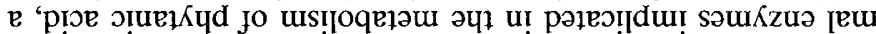

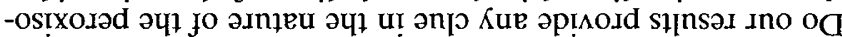

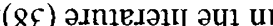

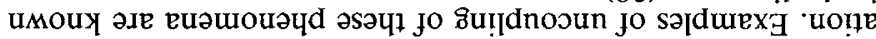

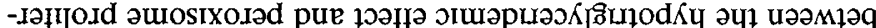

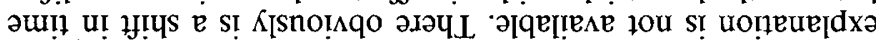
ว†еนdo

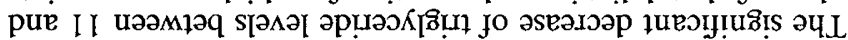

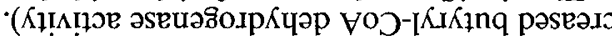

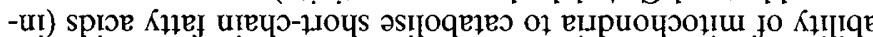

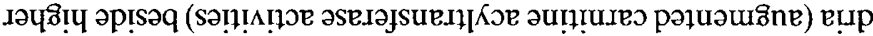

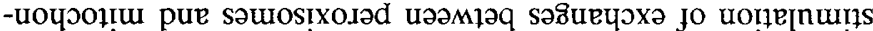

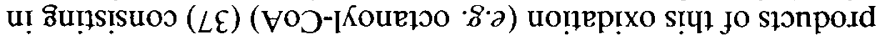

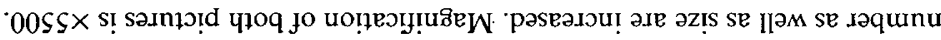

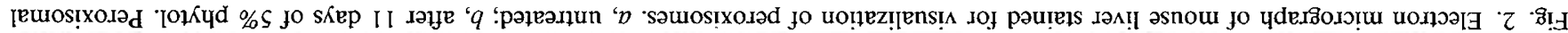
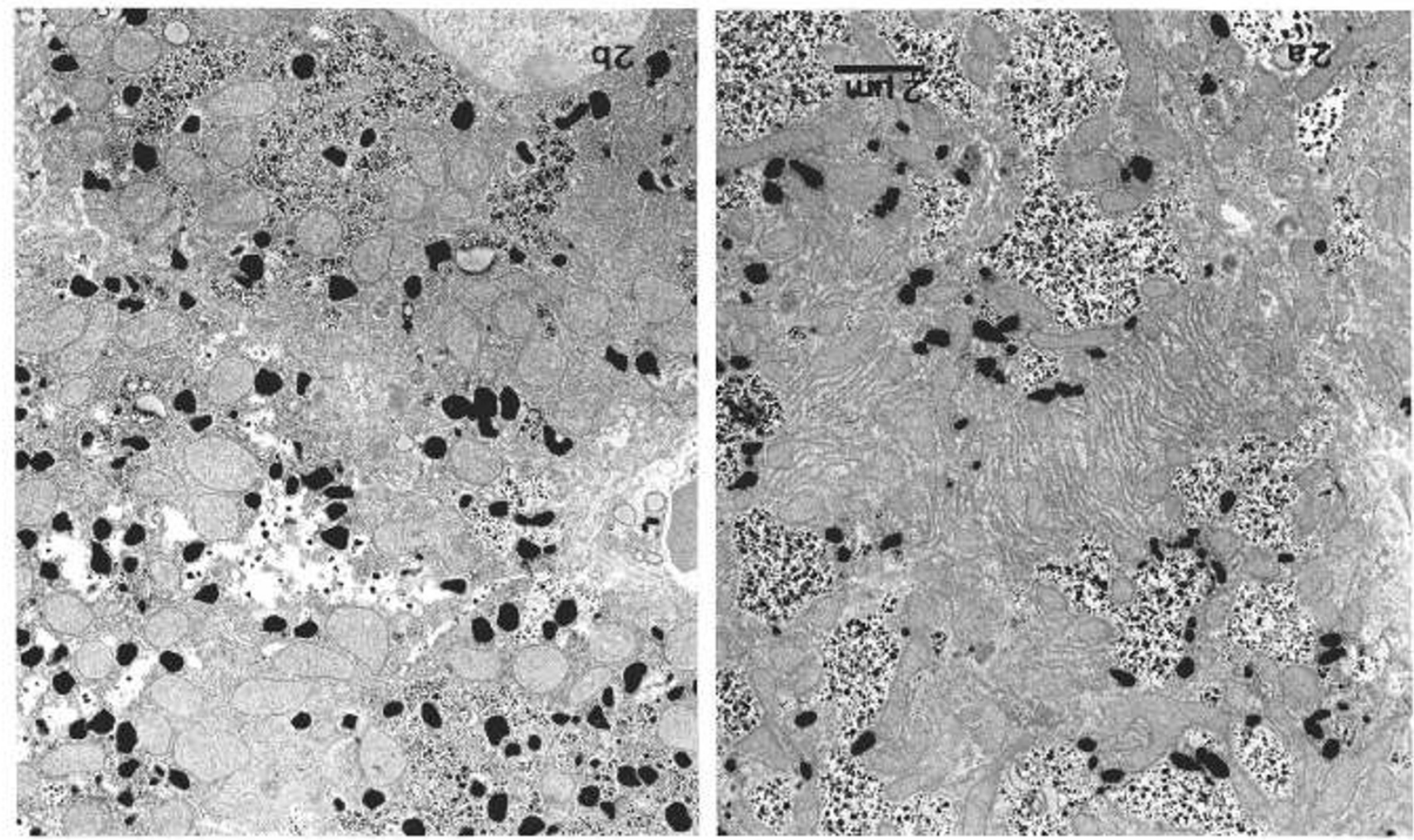

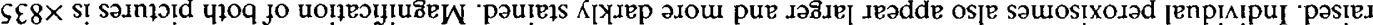

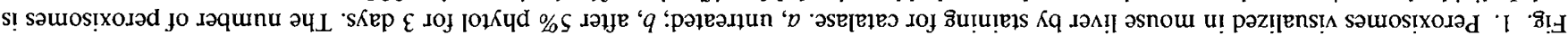

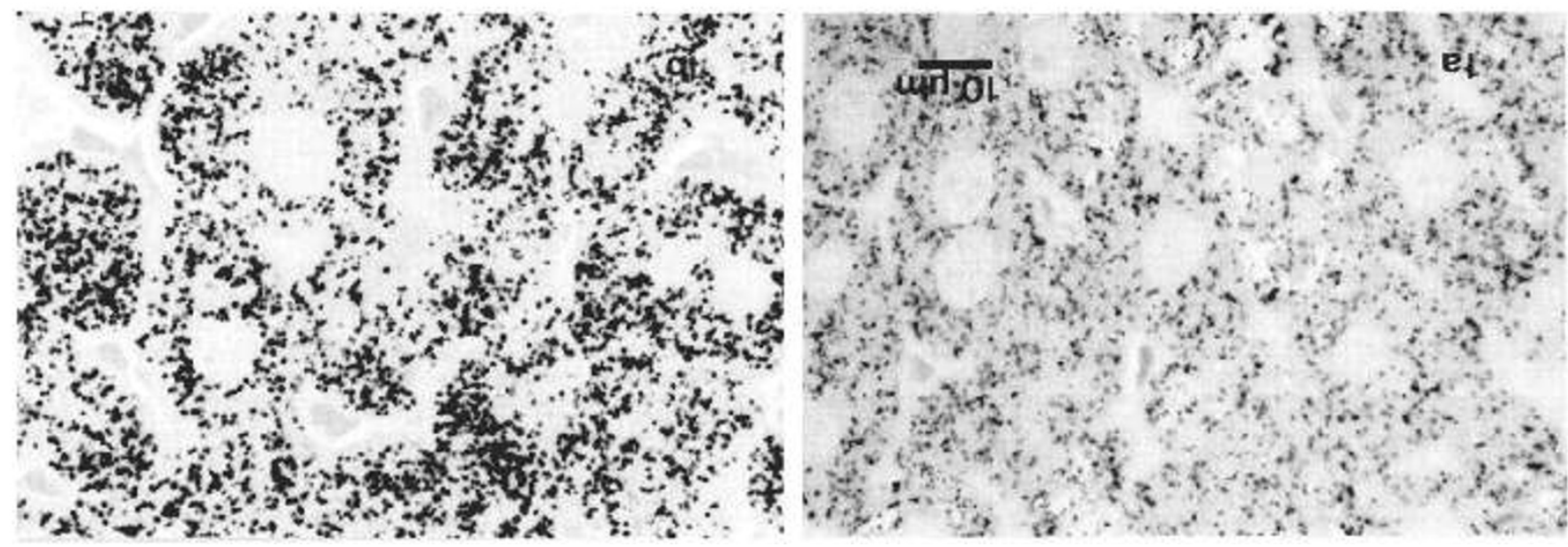



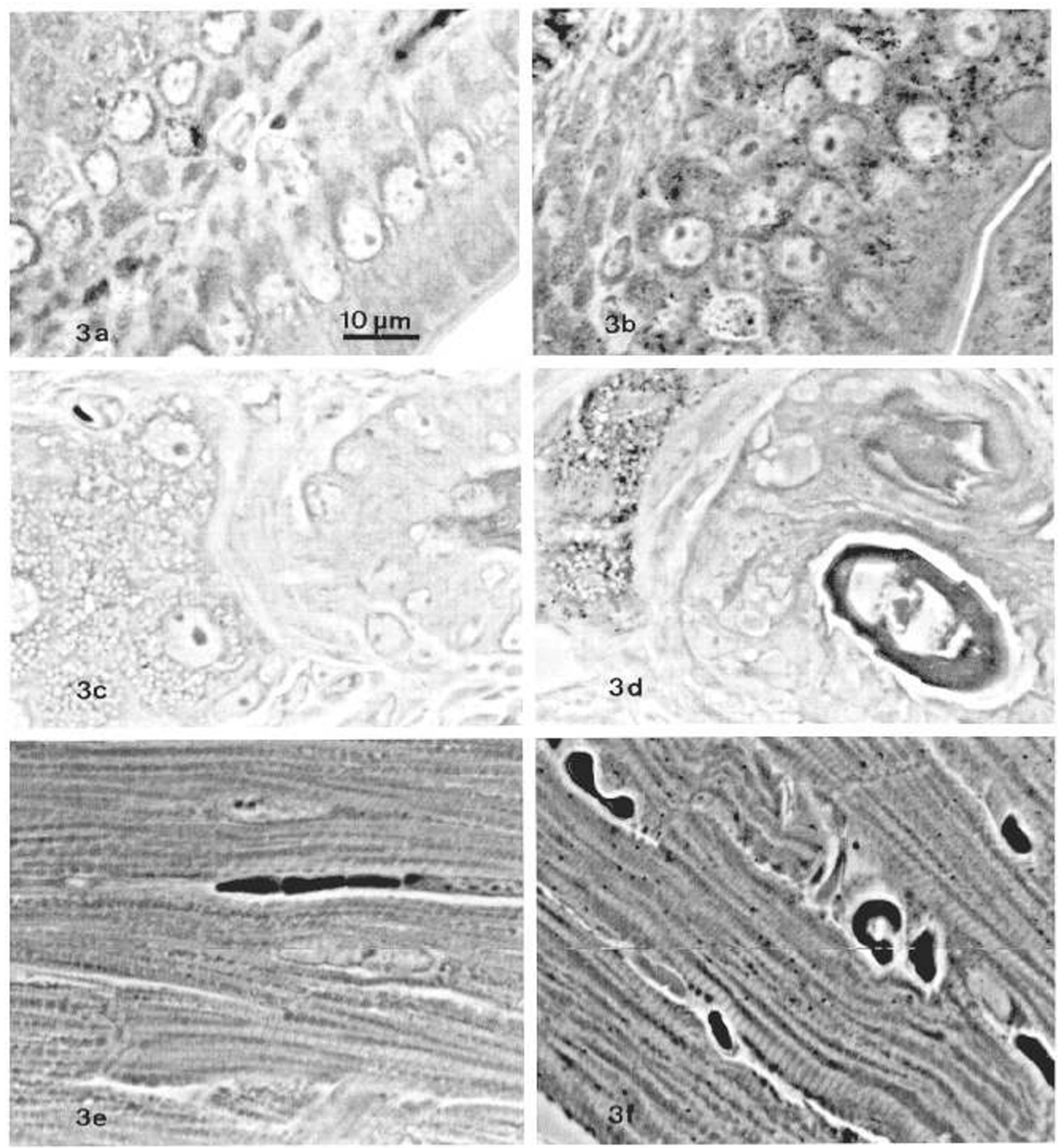

Fig. 3. Cytochemical staining for catalase of mouse duodenum $(a, b)$, cutaneous sebaceous gland $(c, d)$, and myocardium $(e, f)$. By light microscopy no peroxisomes are recognized in untreated animals $(a, c, c)$. After $5 \%$ phytol feeding for 5 days $(b, d, f)$ peroxisomes become conspicuous in all three organs. Magnification of all the pictures is $\times 1300$ (phase contrast).

mal $\beta$-oxidation enzymes after phytol feeding suggest a role for peroxisomes in the latter metabolic phase of phytanic acid breakdown. For this reason, the absence of normal peroxisomes in infantilc Refsum's disease might explain the accumulation of phytanic acid, because our results demonstrate that the opposite (destruction of peroxisomes by phytanic acid) does not occur.

It is striking that the phytol effect is selective for some cell types, while in others no change is visible by light microscopy. Our experiments show peroxisome proliferation following phytol diet in liver, duodenal epithelium, myocardium, and skin seba- ceous glands, but not in kidneys and adrenal glands. Accumulation of phytanic acid in several body tissues was studied and demonstrates high concentrations in heart and liver $(10 \%$ of total tissue fatty acids after 24 days) and lower concentrations (5\% of total fatty acids) in intestine, skin, and kidney (44). Some data are available about the distribution of phytanic acid in the skin of an adult Refsum patient. Large amounts of phytanic acid are present in lipid containing vacuoles in the cytoplasm, mainly in the basal layer of the epidermis (45). It is tempting to relate this to the proliferation of peroxisomes in sebaceous glands, but this 
relationship is missing in the kidney. Renal proximal tubular epithelium normally contains numerous large peroxisomes. In Zellweger's cerebrohepatorenal syndrome peroxisomes are absent in kidneys as well as in liver. No data are available about renal peroxisomes in Refsum's disease. Phytanic acid is excreted in urine (46), but after a large diet dose and in Refsum patients there is also considerable accumulation $(35,47)$ in the kidney. It is not known if phytanic acid undergoes transformation by renal tubular cells.

Acknowledgment. Marina Pauwels (Brussels) prepared the cytochemical stains for light and electron microscopy.

\section{REFERENCES}

1. Klenk E, Kahlke W 1963 Uber das Vorkommen der 3,7,11,15-tetramethylhexadecansäure (Phytansäure) in den Cholinestern und anderen Lipoidfraktionen der Organe bei einem Krankheitsfall unbekannter Genese (Verdacht auf Heredopathia atactica polyneuritiformis Refsum-Syndrome). HoppeSeyler's Z Physiol Chemie 333:133-139

2. Steinberg D 1981 Phytanic acid storage disease (Refsum's disease). In: Stanbury JB, Wyngaarden JB, Fredrickson DS, (eds) The Metabolic Basis of Inherited Disease. McGraw-Hill, New York, pp 731-747

3. Sezille G, Biserte G 1970 Etude biochimique de la maladie de Refsum. Pathol Biol 18:551-558

4. Gautier JC, Laudat Ph, Rosa A, Gray F, Lhermitte F 1973 Maladie de Refsum. Test de charge en phytol chez un descendant. Nouvelle Presse Med 31:20292032

5. Ribadeau Dumas J-L 1969 La maladie de Refsum. Presse Med 55:2085-2088

6. Klenk E, Kremer GJ 1965 Untersuchungen zum Stoffwechsel des Phytols, dihydrophytols und der Phytansäure. Hoppe-Seyler's Z Physiol Chemie 343:39-51

7. Steinberg D, Avignan J, Mize C, Baxter J 1965 Phytanic acid formation and accumulation in phytol-fed rats. Biochem Biophys Res Commun 19:412416

8. Bernhard K, Ritzel G 1953 Beitrage zur Pathologie des Fettstoffwechsels. Phytol, ein neuer lipotroper Faktor der Nahrung. Hoppe-Seyler's Z Physiol Chemie 295:187-197

9. Bernhard K, Wagner H 1954 Beeinflussung des Leber-Fettstoffwechsels durch Phytol. Helvetica Chim Acta 37:2356-2360

10. Steinberg D, Avignan J, Mize CE, Baxter JH, Cammermeyer J, Fales HM, Highet PF 1966 Effects of dietary phytol and phytanic acid in animals. J Lipid Res 7:681-692

11. Stokke O 1967 Alpha-oxidation of fatty acids in various mammals, and a phytanic acid feeding experiment in an animal with a low alpha-oxidation capacity. Scand J Clin Lab Invest 20:305-312

12. Mize CE, Steinberg D, Avignan J, Fales HM 1966 A pathway for oxidative degradation of phytanic acid in mammals. Biochem Biophys Res Commun 25:359-365

13. Scotto JM, Hadchouel M, Odièvre M, Laudat MH, Saudubray JM, Dulac O, Beucler I, Beaune P 1982 Infantile phytanic acid storage disease, a possible variant of Refsum's disease: Three cases including ultrastructural studies of the liver. J Inherited Metab Dis 5:83-90

14. Bolthauser E, Spycher MA, Steinmann B, Briner J, Isler W, Kuster T, Poulos A, Pollard AC 1982 Infantile phytanic acid storage disease: a variant of Refsum's disease. Eur J Pediatr 139:317

15. Ogier H, Roels F, Cornelis A, Poll-The BT, Scotto JM, Odièvre M, Saudubray JM 1985 Absence of hepatic peroxisomes in a case of infantile Refsum's disease. Scand J Clin Lab Invest 45:767-768

16. Roels F, Cornelis A, Poll-The BT, Aubourg P, Ogier H, Scotto JM, Saudubray JM Hepatic peroxisomes are deficient in infantile Refsum's disease. A cytochemical study of 4 cases. Am J Med Genet (in press)

17. Poulos A, Sharp P 1984 Plasma and skin fibroblast $C_{26}$ fatty acids in infantile Refsum's disease. Neurology 34:1606-1609

18. Poulos A, Sharp P, Whiting M 1984 Infantile Refsum's disease (phytanic acid storage disease): a variant of Zellweger's syndrome? Clin Genet 26:29-36

19. Stokke O, Skrede S, Ek J, Bjorkman I 1984 Refsum's disease, adrenoleukodystrophy and the Zellweger's syndrome. Scand J Clin Lab Invest 44:463-470

20. Goldfischer S, Collins J, Rapin I, Coltoff-Schiller B, Chang C-H, Nigro M,
Black VH, Javitt NB, Moser HW, Lazarow P 1985 Peroxisomal defects in neonatal-onset and X-linked adrenoleukodystrophies. Science 227:67-69

21. Moser HW, Moser AE, Singh J, O'Neill BP 1984 Adrenoleukodystrophy: Survey of 303 cases: Biochemistry, diagnosis and therapy. Ann Neurol 16:628-641

22. Kelley RI 1983 The cerebrohepatorenal syndrome of Zellweger, morphologic and metabolic aspects. Am J Med Genet 16:503-517

23. Arias JA, Moser AB, Goldfischer SL 1985 Ultrastructural and cytochemical demonstration of peroxisomes in cultured fibroblasts from patients with peroxisomal deficiency disorders. J Cell Biol 100:1789-1792

24. Beard ME, Sapirstein V, Kolodny EH, Holtzman E 1985 Peroxisomes in fibroblasts from skin of Refsum's disease patients. J Histochem Cytochem 33:480-484

25. Van Hoof $\mathrm{F}$, Hue L Vamecq J, Sherratt HSA 1985 Protection of rats by clofibrate against the hypoglycaemic and toxic effects of hypoglycin and pent-4-enoate. Biochem J 229:387-397

26. Van den Branden C, Kerckaert I, Roels F 1984 Peroxisomal $\beta$-oxidation from endogenous substrates. Demonstration through $\mathrm{H}_{2} \mathrm{O}_{2}$ production in the unanaesthetized mouse. Biochem J 218:697-702

27. Vamecq J, Van Hoof $F 1984$ Implication of a peroxisomal enzyme in the catabolism of glutaryl-CoA. Biochem J 221:203-211

28. Miyazawa S, Ozasa H, Osumi T, Hashimoto $\Upsilon 1983$ Purification and properties of carnitine octanoyltransferase and carnitine palmitoyltransferase from rat liver. J Biochem (Tokyo) 94:529-542

29. Ikeda Y, Dabrowski C, Tanaka K 1983 Separation and properties of five distinct acyl-CoA dehydrogenases from rat liver mitochondria. J Biol Chem 258:1066-1076

30. Siedel J, Hägele ED, Ziegenhorn J, Wahlefeld AW 1983 Reagent for the enzymatic determination of serum total cholesterol with improved lipolytic efficiency. Clin Chem 29:1075-1080

31. Wahlefeld AW 1974 Triglycerides. Determination after enzymatic hydrolysis. In: Bergmeyer HU, (ed) Methods of Enzymatic Analysis, Vol 4. Academic Press, Inc, New York, pp 1831-1835

32. Snedecor GW, Cochran WG 1967 Statistical Methods. Iowa State University Press, Ames, IA, pp 120-132

33. Roels F, Goldfischer S 1979 Cytochemistry of human catalase: the demonstration of hepatic and renal peroxisomes by high temperature procedure. $J$ Histochem Cytochem 27:1471-1477

34. Roels F, Wisse E, De Prest B, van der Meulen J 1975 Cytochemical discrimination between catalases and peroxidases using diaminobenzidine. Histochemistry $41: 281-312$

35. Hansen RP, Shorland FB, Prior IAM 1968 The occurrence of 4,8,12-trimethyltridecanoic acid in the tissues of rats fed high levels of phytanic acid. Biochim Biophys Acta 152:642-644

36. Avignan J 1966 The presence of phytanic acid in normal human and animal plasma. Biochim Biophys Acta 116:391-394

37. Mannaerts GP, Debeer LJ 1981 Beta-oxidation of fatty acids: relative contribution of mitochondria and peroxisomes. In: Hue $L$, van de Werve $G$, (eds) Short term regulation of liver metabolism. Elsevier/North Holland, Amsterdam, pp 273-290

38. Fahimi HD, Reinicke A, Sujatta M, Yokota S, Ozel M, Hartig F, Stegmeier K 1982 The short- and long-term effects of Bezafibrate in the rat. Ann NY Acad Sci 386:111-137

39. Tsai S-C, Avignan J, Steinberg D 1969 Studies on the alpha oxidation of phytanic acid by rat liver mitochondria. J Biol Chem 244:2682-2692

40. Muralidharan VB, Kishimoto Y 1984 Phytanic acid $\alpha$-oxidation in rat liver. J Biol Chem 259:13021-13026

41. Ishii H, Fukumori N, Horie S, Tsuga T 1980 Effects of fat content in the diet on hepatic peroxisomes of the rat. Biochim Biophys Acta 617:1-11

42. Osmundsen H 1982 Peroxisomal $\beta$-oxidation of long fatty acids: Effects of high fat diets. Ann NY Acad Sci 388:13-27

43. Cannon B, Alexson S, Nedergaard J 1982 Peroxisomal $\beta$-oxidation in brown fat. Ann NY Acad Sci 386:40-57

44. Mize CE, Avignan J, Steinberg D, Pittman RC, Fales HM, Milne GWA 1969 A major pathway for the mammalian oxidative degradation of phytanic acid. Biochim Biophys Acta 176:720-739

45. Reynolds DJ, Marks R, Davies MG, Dykes PJ 1978 The fatty acid composition of skin and plasma lipids in Refsum's disease. Clin Chim Acta 90:171-177

46. Hansen RP, Shorland FB, Prior IAM 1966 The fate of phytanic acid when administered to rats. Biochim Biophys Acta 116:178-180

47. Kahlke W, Richterich R 1965 Refsum's disease (Heredopathia atactica polyneuritiformis): an inborn error of lipid metabolism with storage of $3,7,11,15$ tetramethyl hexadecanoic acid. Am J Med 39:237-241 